\title{
Prediction of changes in managerial competencies in the period of digitization
}

\author{
Zdenko Stacho ${ }^{1[0000-0001-5588-8340]}$, Ján Gróf ${ }^{2}$ and Michal Lukáč ${ }^{3}$ \\ ${ }^{1}$ Institut of management, University of Ss. Cyril and Methodius in Trnava, 91701 Trnava, Slo- \\ vakia \\ zdenko.stacho@ucm.sk \\ ${ }^{2}$ Faculty of Management Comenius University, Bratislava 820 05, Slovakia \\ jan.grofefm.uniba.sk \\ ${ }^{3}$ University of Ss. Cyril and Methodius in Trnava, 91701 Trnava, Slovakia \\ michal.lukac@ucm.sk
}

\begin{abstract}
Given the beginning of the era of digitization, it is necessary to assess the readiness of companies not only in Slovakia for the changes it brings. The intensification of the implementation of digital technologies, supported by the current pandemic situation, is putting pressure on companies and their managers. In an effort to maintain or increase competitiveness, they must be able to react flexibly. The authors of this paper focus on the analysis of the current and expected state of application of key managerial competencies in the era of the coming digitization in companies operating in Slovakia. The research was carried out using the questionnaire method in 197 companies, and the results show an aboveaverage use of almost all assessed competencies and a positive vision for the future, as the perception of the need to apply them is even higher than the current situation.
\end{abstract}

Keywords: era of digitization, key managerial competencies, industry 4.0

\section{Introduction}

Start of the Fourth Industrial Revolution will result in a change in the competitive position not only of enterprises (Lorincová et al. 2020; Hitka et al. 2018, Kohnova et al. 2020, Kirchmayer, Fratričová 2018), but also of entire national economies (Hitka et al. 2015; Stacho et al., 2019, Papula et al., 2019). The influences and trends in the development of industry 4.0 are the subject of professional discussions and the content of calls for research activities not only in technical but also in sociological and economic sciences (Helmrich, 2015; Hermann et al., 2016; Hofmann, Rüsch, 2017, Bartuška et al. 2016, Kucharčíková et al. 2015, Rats et al. 2015, Levický et al 2013). In addition to research and educational institutions, this trend is also perceived by economic practice and more and more companies are aware of the need to implement changes in management systems, which are a challenge now and a condition for competitiveness in the future. Many scientific studies published to date suggest that the fourth industrial revolution (Industry 4.0) will literally revolutionize business management in the coming 
period (Stock, Seliger, 2016; Wang et al., 2016; Deloite, 2015; McKinsey \& Company, 2016, Jankelová et al., 2017, Raišienè et al 2020).

In order to meet customer expectations related primarily to the short lead time to market for innovative products, companies are introducing intelligent elements into production systems in order to create the necessary flexibility and capacity (Schaeffer, 2017; Stanek, Pauhofova, 2016; BCG, 2015). Simple and monotonous processes are automated (Stacho et al. 2020), while other processes become more complex and interconnected. The Internet is becoming a platform on which amounts of data obtained from various sources pass from customers to manufacturers and back. The ability of products to obtain, process and send information to the production process led to the emergence of the Internet of Things (IoT) (KPMG, 2016; PWC, 2014; European Parliament, 2015). This phenomenon already affects not only industry or the economy, but also in society.

Identifying changes in the nature of managerial work, and defining the characteristics of the modern world of managerial work requires the development of the framework of the business environment from a macroeconomic point of view. This environment influences the formation of demands on the competitiveness of companies and the definition of the required competence of employees and managers. The competencies of a manager represent a complex of knowledge, abilities, skills, experiences and, of course, physical and mental readiness to use these qualities to effectively perform the assigned tasks in accordance with the assigned authority (Stacho, Stachová 2017).

Knowledge, education or sectoral qualifications are facing the requirements of flexibility in the current labor market. Intelligent and flexible processes characterize the manufacturing companies of the future (Tomek and Vavrová 2017). Competences and time are becoming a commodity of the world of work in the era of industry 4.0.

In the era of advanced digitization and hyperconnectivity of the knowledge society, the competence of managers is defined by the content of the commodity in the labor market of industry 4.0 (Hecklaua et al., 2016). The analysis of manager competence is the starting point for defining specialized strategies for job creation and employee workforce management. Models describing potential competence of managers and the relationships between them, which show a divergence of actual and expected competencies, are a tool for increasing the available managerial potential in the 4.0 industry era.

The main focus of current studies is on the impact of automation and computer intensification on changes in employment. However, assumptions and forecasting studies need to be confronted with the views and intentions of companies and their managers.

From the point of view of several entities, there is insufficient knowledge today about the expected changes in the skills and competencies of managers in industry 4.0.

Hecklau and his team applied the analysis of the external environment as a characteristic that defines competencies in the world of work 4.0 with regard to the influence of economic, social and technical factors. (pozri Chyba! Nenašiel sa žiaden zdroj odkazov.) (Hecklaua, Galeitzkea, Flachsa, Kohlb, 2016). 
Table 1. Key competencies of employees in the world of work 4.0 (Hecklaua, Galeitzkea, Flachsa, Kohlb, 2016)

\begin{tabular}{cc}
\hline Enviroment & Competencies \\
\hline & Ongoing globalization \\
& multi-cultural skills, tolerance tolerance, language skills, \\
& time flexibility, ability to communicate, understand the \\
process & The growing need for innovation \\
& entrepreneurial thinking, creativity, problem solving, \\
& working under pressure, using the latest knowledge, \\
& developing technical skills, research skills, understanding \\
& the process \\
Demand for higher service orientation & conflict resolution, communication skills, ability to \\
& compromise, networking \\
& The growing need for cooperation and interaction \\
& ability to be compromise and cooperative, ability to work in \\
the team, communication skills, network skills
\end{tabular}

In the context of the above, the authors of the paper decided to analyze the application of key management competencies in the era of the coming digitization in companies operating in Slovakia.

\section{Materials a Methods}

In the article was used data obtained from research activities of the Slovak Academic Association for Personnel Management SAAPM. The survey was carried out in 
the form of a questionnaire in the months of February to May 2020, while the questionnaire was delivered to the respondents electronically and 197 respondents took part in
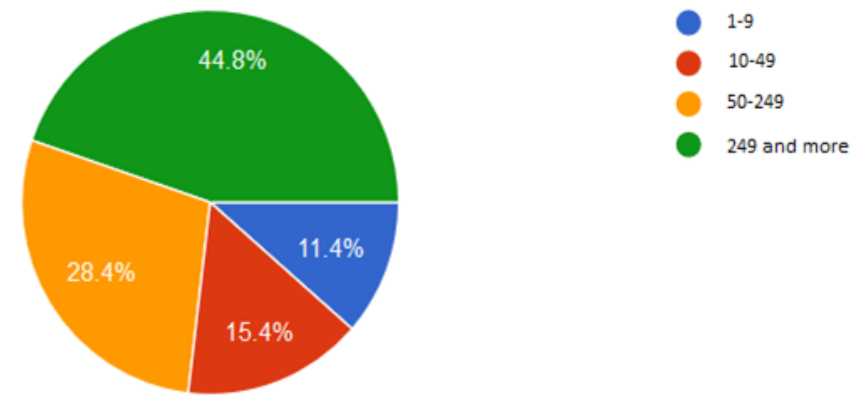

it from the same number of companies operating in Slovakia. Almost 45\% of respondents were companies with more than 250 employees (Figure 1).

Fig. 1. Number of employees in the company

The enterprises involved in the survey operate in various sectors of the economy, $48.3 \%$ of them operating in industrial production, $35.8 \%$ in services and the other $15.9 \%$ in other sectors.

From the point of view of business ownership, $57.7 \%$ of companies are with a majority ownership from Slovakia and $45.7 \%$ of companies with a majority ownership from abroad were involved in the survey.

The settlement structure of individual respondents is shown in Figure 2.

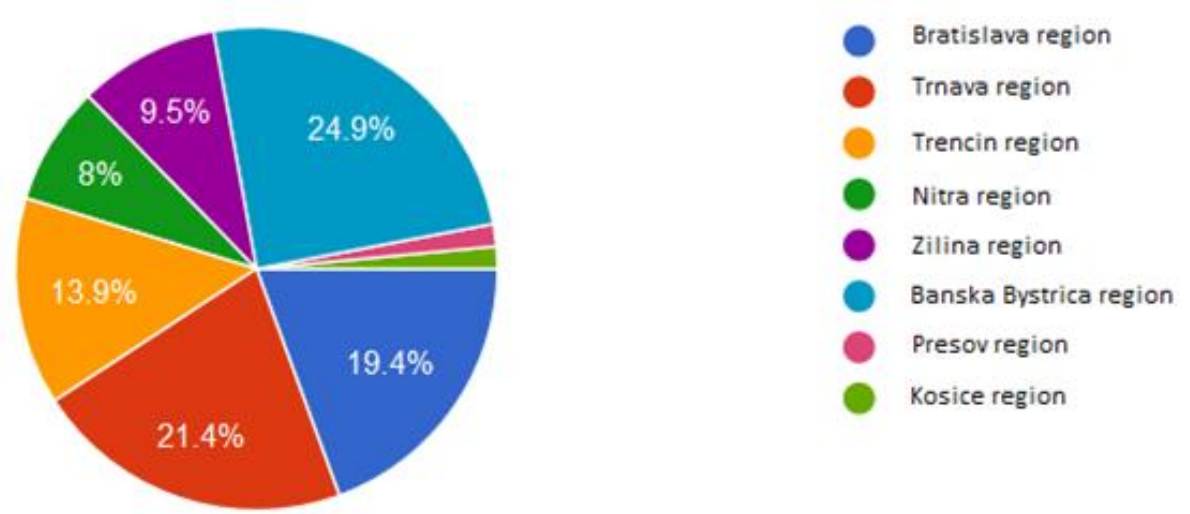

Fig. 2. Settlement structure of the enterprises

To evaluate the current state as well as the perception of the need of development, the authors used a five-part Likert scale of assessment. 


\section{Results}

For the purposes of this article, the authors statistically processed the results from questions focused on the current level (on a scale from not applicable at all to fully applied) of the application of key competencies in the era of emerging digitization, such as:

- Critical thinking,

- Creativity and creative thinking,

- Analytical thinking (capturing, structuring and understanding information),

- Technological and IT skills, working with specific software,

- Employee orientation (motivation, leadership, employee development ...),

- Ability of self-motivation

On the other hand, they analyzed the perception of the importance (on a scale from insignificant to very important) of the application of these competencies in the future.

The results of the survey showed that in the individual analyzed managerial competencies required for the effective implementation of the concept of digitization in practice, the respondents on the Likert five-point scale reach values from 2.39 to 4.07 (Fig.3).

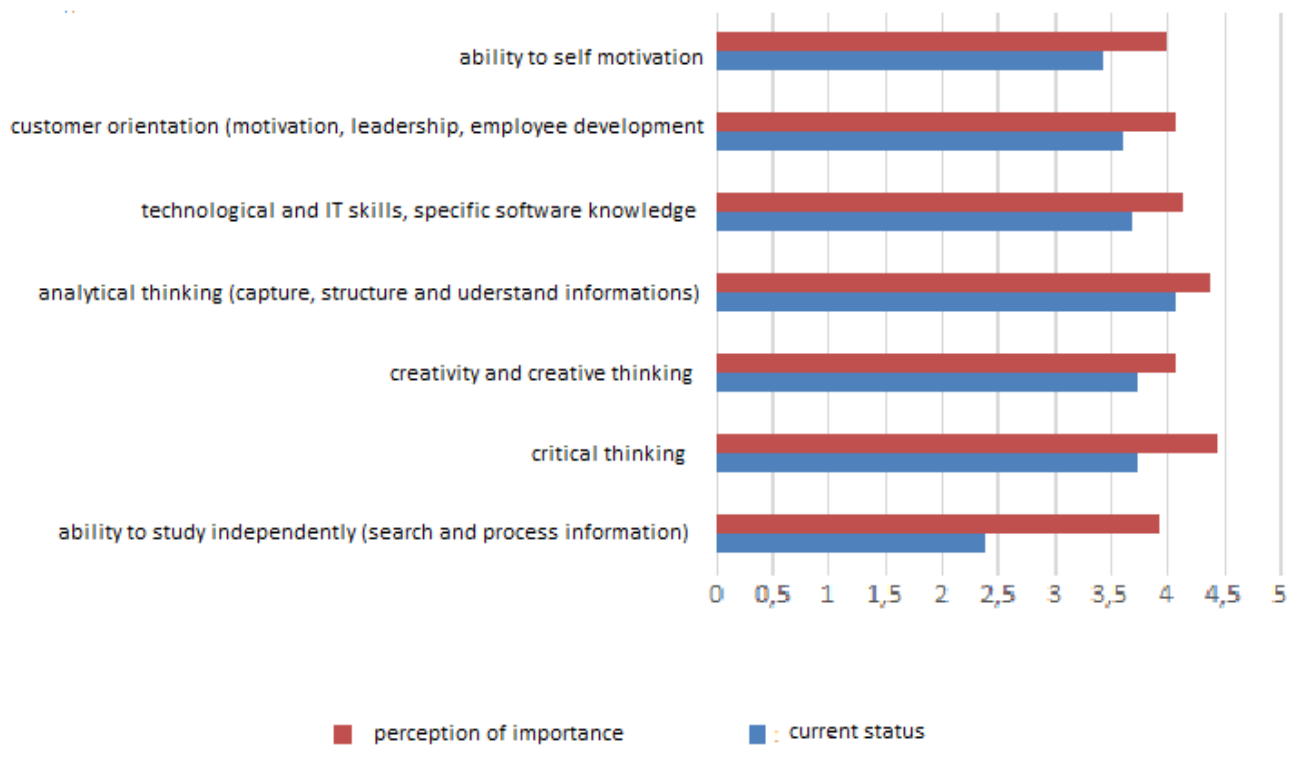

Fig. 3. Current state vs. perception of the importance of applying key managerial competencies

The highest value (4.07) is achieved by respondents in the competence of managers to use analytical thinking in their work and on the other hand the lowest level (2.39) is achieved in the ability of self-study. 
Acknowledgments: This research was supported by project APVV-17-0656 Transformation of Paradigm in Management of Organizations in the Context of Industry 4.0 and academic association SAAPM.

\section{Conclusion}

The analysis of the readiness of companies in Slovakia for the start of the era of digitization is important mainly due to the support of the competitiveness of the Slovak economy in a global hypercompetitive environment. The authors of this paper analyzed the current availability of key managerial competencies of managers operating in companies in Slovakia in an effort to identify not only readiness but also potential for further development. The results of a survey conducted on a sample of 197 companies showed that in the majority of the analyzed key competencies, managers reach an above-average level, i. they apply these competencies in their practice, although not to the maximum extent possible, while the average level reached the value of 3.57 points. On the other hand, this result expresses a relatively significant deficit that will need to be eliminated in the near future. On the positive side, however, the finding is that the respondents are aware of the justification for focusing on increasing the rate of application of key managerial competencies in the future. The survey showed that the perception of the importance of these attributes reached the average level of respondents up to 4.15 points and the perception of the importance of some competencies reached a level higher than 4.35 points on a 5-part scale. Such a result suggests that the orientation of the company and the managers in them will in the near future focus on increasing their application in managerial practice.

\section{Acknowledgment}

Abstract. The research, whose results were processed in this paper was supported by the grant APVV-17-0656 entitled Transformation of Organizational Management Paradigm in the Context of Industry 4.0

\section{$5 \quad$ References}

1. Bartuska, L., Hanzl, J., \& Lizbetinova, L. (2016). Possibilities of Using the Data for Planning the Cycling Infrastructure. Procedia Engineering, 161, 282-289. https://doi.org/10.1016/j.proeng.2016.08.555

2. BCG: Industry 4.0, The Future of Productivity and Growth in Manufacturing Industries.Capgeminy Consulting In: Industry 4.0 - The Capgeminy Consulting View, Sharpening the Picture beyond the Hype (2015).

3. Berger, R.: Industry 4.0, The new industrial revolution, How Europe will succeed, (2014).

4. Deloite: Industry 4.0, Challenges and solutions for the digital transformation and use of exponential technologies (2015).

5. European Parliament: Industry 4.0. Digitalisation for productivity and growth. online: www.europarl.europa.eu/Reg-

Data/etudes/BRIE/2015/568337/EPRS_BRI(2015)568337_EN.pdf (2015). 
6. Hecklaua, F., Galeitzkea, M., Flachsa, S., Kohlb, H.: Holistic approach for human resource management in Industry 4.0 In. 6th CLF - 6th CIRP Conference on Learning Factories, Procedia CIRP 54. (2016).

7. Helmrich K.: Digital Enterprise - Fertigungs- und Prozessindustrie auf dem Weg zu Industrie 4.0. Handelsblatt Journal -Sonderveröffentlichung zum Thema „Industrie 4.0 (2015).

8. Hermann, M., Pentek, T., Otto, B.: Design principles for industrie 4.0 scenarios. Proceedings of the International Conference on System Sciences, 3928-3937 (2016).

9. Hitka, M.; Kozubikova, L.; Potkany, M. Education and Gender-Based Differences in Employee Motivation. Journal Of Business Economics And Management 9 (1) 80-95 (2018)

10. Hitka, M.; Závadská, Z.; Jelačić, D.; Balážová, Ž. Qualitative indicators of company employee satisfaction and their development in a particular period of time. Drvna industrija: Znanstveni časopis za pitanja drvne tehnologije 66(3), (2015). 235-239. doi.org/10.5552/drind.2015.1420

11. Hofmann, E., Rüsch, M.: Industry 4.0 and the current status as well as future prospects on logistics. Computers in Industry Journal 89, 23-34 (2017).

12. Jankelová, N.; Joniaková, Z.; Blštáková, J.; Némethová, I. Readiness of human resource departments of agricultural enterprises for implementation of the new roles of human resource professionals. - Agricultural economics, 63(10), 461-470, doi:10.17221/189/2016AGRICECON (2017).

13. Kirchmayer, Z., Fratricova, J. What Motivates Generation Z at Work? Insights into Motivation Drivers of Business Students in Slovakia In: 31st International-Business-InformationManagement-Association Milan, ITALY, APR 25-26, (2018)

14. Kohnová L., Papula J., Papulová Z. Cooperation Models for Employee Education: Analysis on Slovak and Czech Companies. Mobility Internet of Things 2018. Mobility IoT 2018. EAI/Springer Innovations in Communication and Computing. Springer, Cham, (2020) ISBN 978-3-030-30910-7, https://doi.org/10.1007/978-3-030-30911-4_22

15. KPMG: The Factory of the Future, Industry 4.0 - The challenges of tomorrow (2016).

16. Kucharčíková, A., Tokarčíková, E., Blašková, M.: (2015) Human Capital Management Aspect of the Human Capital Efficiency in University Education. Procedia - Social and Behavioral Sciences Volume 177, 22 April 2015, Pages 48-60. ISSN 1877-0428 http://www.sciencedirect.com/science/article/pii/S1877042815016869\#

17. Levicky, M., Gurcik, L., Porhajas, V., Horvathova, J. 2013. Some aspects of time-demand in the beekeeping production process in Slovakia. PROCEEDINGS FROM VIII. INTERNATIONAL CONFERENCE ON APPLIED BUSINESS RESEARCH (ICABR 2013), APR 22-26, 2013 East London: SOUTH AFRICA

18. Lorincová, S.; Hitka, M.; Štarchoň, P.; Stachová, K. Strategic instrument for sustainability of human resource management in small and medium-sized enterprises using management data. Sustainability 10(10), 3687, (2018). doi:10.3390/su10103687

19. McKinsey \& Company: Industry 4.0 after the initial hype, Where manufacturers are finding value and how they can best capture it, (2016).

20. PAC-IT: Trends in der Automobil - IT-Investitionspläne in Deutschland, (2013) online: https://www.pac-online.com/industrie-40-der-automobilindustrie-aktuell-noch-geringe-bedeutung

21. Papula J., Kohnová L., Papulová Z., Suchoba M. (2019) Industry 4.0: Preparation of Slovak Companies, the Comparative Study.Smart Technology Trends in Industrial and Business Management. EAI/Springer Innovations in Communication and Computing.Springer, ISBN 978-3-319-76998-1 https://doi.org/10.1007/978-3-319-76998-1_8

22. Potkany, M., Stachova, K. Required skills and abilities of facility manager on strategic level of managing in Slovak companies In: Economic Annals-XXI 3-4(1), pp. 55-59 (2015). 
23. PWC: Industry 4.0, Opportunities and challenges of the industrial internet (2014).

24. Raišienè, A.G., Rapuano, V., Varkulevičiūte, K., Stachová, K. 2020. Working from home who's happy? A survey of Lithuania's employees during the Covid-19 quarantine period. Sustainability

25. Schaeffer, E.: Industry X.0: Realizing Digital Value in Industrial Sectors. Redline Verlag, Munchen (2017).

26. Stacho, Z., Stachová, K. Organizácia manažérskej práce. Bratislava: Wolters Kluwer, (2017).

27. Stacho, Z., Stachova, K., Caganova, D. 2020. Participation of all Employee Categories in Innovation Processes in Slovak Organisations. Mobile networks \& applications 25(3) 853859. https://doi.org/10.1007/s11036-020-01518-2

28. Stacho, Z.; Stachova, K.; Papula, J.;Papulova, Z.; Kohnova, L., Effective Communication in Organisations Increases Their Competitiveness. Polish Journal of Management Studies 19(1) pp. 391-403 (2019).

29. Stanek P, Pauhofova I.: Adaptačné procesy a pulzujúca ekonomika v cylke paradigmy zmien v 21. storoční. EU SAV, Bratislava (2016).

30. Stock T, Seliger, G.: Opportunities of Sustainable Manufacturing in Industry 4.0. Procedia, CIRP 40: 536-541, (2016).

31. Tomek, G, Vavrova, V.: Prumysl 4.0 aneb nikdo sam nevyhraje. Pruhonice: Professional Publishing, (2017)

32. Wang, S., Wan, J., Zhangb, D., Lia, D., Zhanga, C.: Towards smart factory for industry 4.0:a self-organized multi-agent system with big data based feedback and coordination. Computer Networks 101, 158-168, (2016). 